\title{
共生進化に基づく帰納論理プログラミングの 予測精度の向上
}

\section{Using Symbiotic Evolution to Improve the Predictive Accuracy for Inductive Logic Programming}

\author{
大谷 紀子
}

大和田 勇人

\section{東京理科大学理工学部経営工学科}

otani@ia.noda.sut.ac.jp

(同上)

ohwada@ia.noda.sut.ac.jp

keywords: inductive logic programming, optimal hypothesis search, genetic algorithm, symbiotic evolution

\section{Summary}

This paper describes a method for optimal hypothesis search in Inductive Logic Programming(ILP). The method is based on symbiotic evolution, a variant of genetic algorithm (GA), for improving the predictive accuracy in classifying unknown examples. Progol, the representative ILP system, employs a refinement operator and finds an optimal hypothesis which subsumes the most specific hypothesis. Progol focuses on a hypothesis which has maximum explanatory power for training data. However, ILP systems should be evaluated by their explanatory powers for unknown data.

In contrast, the proposed method produces a hypothesis using symbiotic evolution, which maintains and evolves two populations: a population of partial solutions to the problem and a population of complete solutions which are formed by grouping several partial solutions together. Symbiotic evolution can conduct balanced optimization of partial solutions and complete solutions. We postulate that the diversity of the results in GA increases the fitness to unknown data.

We have developed an ILP system called ILP/SE, which uses symbiotic evolution for the hypothesis search task and uses the learning algorithm of Progol for the other task. ILP/SE judges the class of unknown data by majority using multiple hypothesises obtained in repeated execution. Experiments were conducted to show the performance of ILP/SE using the mutagenesis dataset. The result indicates that the ILP/SE approach outperforms the previous method using Progol for classification accuracy.

\section{1.はじめ に}

帰納論理プログラミング (Inductive Logic Programming, ILP) は, 帰納推論と論理プログラミングを統合 した機械学習の手法であり, 背景知識の利用と一階述語 論理による知識表現を特徵とする [古川 97] .これまでに FOIL [Quinlan 95], Progol [Muggleton 95] 等の ILP システムが開発され, 多くの実世界問題に適用されてき たが , 近年はデータマイニングの分野でも注目を浴びて おり，応用可能性が期待されている [溝口 97] .

入力が基底アトムに限定されている FOIL に対し , Progol は任意の Horn 節により背景知識が記述できるため， 種々の問題への適用が可能である. Progolの学習過程は， 最弱仮説生成と最適仮説探索の 2 段階に大別される . 後 者の段階では，最弱仮説で限定された仮説空間を $\mathrm{A}^{*}$-like アルゴリズムに従って探索し，最適仮説を発見する . 探
索における仮説の評価は，主に被覆する訓練事例の数に よって決定され，最も多くの訓練事例を説明する仮説を 最適仮説と判断する．しかし，ILP システムでは予測問 題を対象とする場合が多く，訓練事例に加えて未知事例 をも正しく説明することが要求される . 従って , 未知事 例における予測精度の向上は重要な研究目標といえる.

最適化問題の解法として広く利用されている遺伝的ア ルゴリズム (Genetic Algorithm, GA) では , 構造が不明 確で広大な解空間における最適解探索が可能であり，最適 性の定義があいまいな問題にも有効である . 学習対象や形 態に応じた樣々な GA のモデルの 1 つとして , Moriarty らにより共生進化 (symbiotic evolution) が提案されてい る [Moriarty 96, Moriarty 98] . 共生進化では, 部分解 を個体とする集団と，部分解の組み合わせを個体とする 全体解集団を保持し，両集団を並行して進化させる．部 分解集団では解の部分的評価を行ない，最適解に含まれ 
得る多樣な部分解を生成する，光れらのより良い組み合 わせを全体解集団において学習することで，1 集団を進 化させる GA よりも多樣な解候補からの探索を行なうこ とができる .

本研究では, 未知事例の分類における予測精度の向上 を目的とする . 未知事例の予測精度の高い解は, 必ずし も訓練事例で一番正解率の高い解ではなく, 訓練事例で ある程度の正解率を達成している局所解のうちのいずれ かと予想される . 共生進化の多樣性から得られる複数の 解候補が予測精度の向上に寄与するとの考えに基づき， 共生進化に基づく ILP の未知事例分類法を提案する.

未知事例分類では，まず最初に，共生進化に基づく仮 説生成を複数回繰り返し, 複数の仮説を生成する.仮説 生成時に行なう最適仮説探索では，仮説空間を形成する ための精密化演算子の 2 つの機能に着目し , 各リテラル の一般化の程度 , および最適仮説に含まれるリテラルの 組み合わせを光れ共生進化の部分解集団と全体解集 団において学習する．次に，得られた複数の仮説によって 未知事例を分類する.最後に，各々の分類結果で多数決を 行ない，より多くの仮説が分類したクラスを末知事例の クラスと判断する. 以上の方法は ILP システム ILP/SE として実現されている.

以下， 2 章で ILP/SE における仮説生成方法の概略を 説明する. 3 章では共生進化に基づく未知事例分類法の 詳細について述べ，ILP/SE のシステム構成を示す . 4 章 では Mutagenesis データによる評価実験の結果を示し， 提案手法の有効性について考察する. 5 章で関連研究と 比較し，最後に 6 章において結論を述べる．

\section{ILP/SE の仮説生成方法}

ILP/SE は Progol の学習アルゴリズムに基づいた方 法で仮説を生成する．本章では，ILP/SE の仮説生成方 法について，Progol との相違点を示しながら概説する．

ILP/SE の入力は , Prolog 形式の Horn 節て記述され た正事例集合 $E^{+}$，負事例集合 $E^{-}$，および背景知識 $B K$ であり，下式を満たす仮説 $H$ を導出する.

$$
\left\{\begin{array}{l}
H \cup B K \models E^{+} \\
H \cup B K \cup E^{-} \not \models \square \\
H=\left\{h_{1}, h_{2}, \ldots, h_{n}\right\}
\end{array}\right.
$$

$h_{1} \sim h_{n}$ は項が変数または定数のP Prolog 節であり，被覆 集合アルゴリズムに従って順次生成される．仮説生成の 手順を図 1 に示す*1.

Step 1 およびStep 2 で生成される節 (仮説空間内の全 仮説)の項は，モード宣言とタイブ情報による制約を満た している，モード宣言は，節を構成するリテラルの各項

*1 Step 1 およびStep 2 の生成物を乥れぞれ最弱仮説，最適仮 説と呼ぶため, 以降では, 仮説 $H$ を構成する節 $h_{1} \sim h_{n}$ をも 仮説と表現する.

\begin{tabular}{|c|c|}
\hline Step 1 & $\begin{array}{l}1 \text { つの正事例 } e_{i} \in E^{+} \text {と背景知識 } B K \text { から }, \text { 逆伴 } \\
\text { 意法によって最弱仮説を求める. }\end{array}$ \\
\hline Step 2 & $\begin{array}{l}\text { Step } 1 \text { で得られた最弱仮説をボトムとする仮説空 } \\
\text { 間を探索し，最適仮説 } h_{i} \text { を導出する. }\end{array}$ \\
\hline Step 3 & $h_{i}$ が被覆する正事例を $E^{+}$から除去する . \\
\hline Step 4 & $E^{+}$が空集合になるまでStep 1〜3 を繰り返す． \\
\hline Step 5 & $\begin{array}{l}\text { 負事例の被覆数が } T_{n e g} \text { 個以下である最適仮説 } h_{i} \\
\text { の集合を } H \text { とする. }\end{array}$ \\
\hline
\end{tabular}

図 1 仮説生成手順

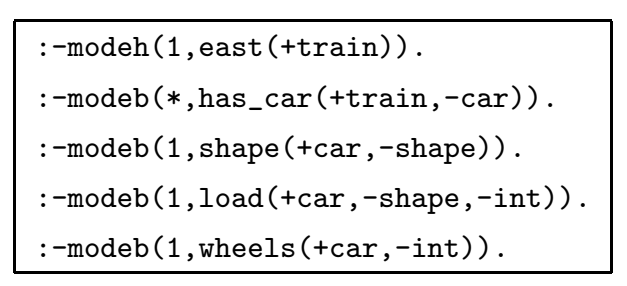

図 2 モード宣言とタイブ情報の記述例 (一部)

に+，一，\#のうちいずれかのモードを割り当て，項の

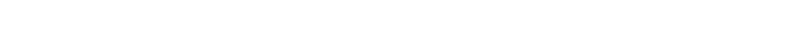
入力引数と出力引数であることを表し, \# モードは定数 項のまま汎化の対象とならないことを表す . ボディの+ モードの項には, 既出 $* 2$ していない変数が入ることはな い . 各項にはタイプ情報も与えられており，各述語の項 の型を規定している . モード宣言とタイプ情報の記述例 を図 2 に示す . modeh は仮説のヘッド , modeb は仮説の ボディのリテラルに関する記述である.第 2 引数の括弧 の前の文字列 (east, has_car, shape, load, wheels) がリテラルの述語名を表し，括弧内で各項のモード (+, -) とタイプ (train, car, shape, int) を指定する.第 1 引数は, 第 2 引数のパターンに合う解の求めるべき個 数 (バックトラック回数) を表す．“*”は解の個数に制限 を加えないことを意味する。

Step 2 で探索する仮説空間は, Step 1 で得られた最 弱仮説をボトム, 最も一般的な単位節 (ただしモード宣 言に矛盾しないもの) をトップとする概念ラティスであ る.仮説空間の例を図 3 に示す．トップの仮説から順に 精密化演算子を適用して特殊化された仮説により，概念 ラティスが構成される . 精密化演算子は，モード宣言と タイプ情報による制約を満たしながら，次の 2 つの機能 を果たすものである

機能 1 異なる变数同士が同じ値をとるようにする.

機能 2 仮説のボディに新たなリテラルを追加する.

この 2 機能によって, 元の仮説に包摂される仮説が逐次 生成され，構築される概念ラティスは包摂束となる. 図 3 の太線は機能 1 による特殊化を表し，普通線は機能 2 による特殊化を表す．最弱仮説を仮説空間のボトムとす るため，機能 1 の代入制約は最弱仮説よりも特殊になら

*2 当該変数を含むリテラルよりも左側のリテラルに同名の変数 が含まれる場合, 兴の変数は「既出している」という. 


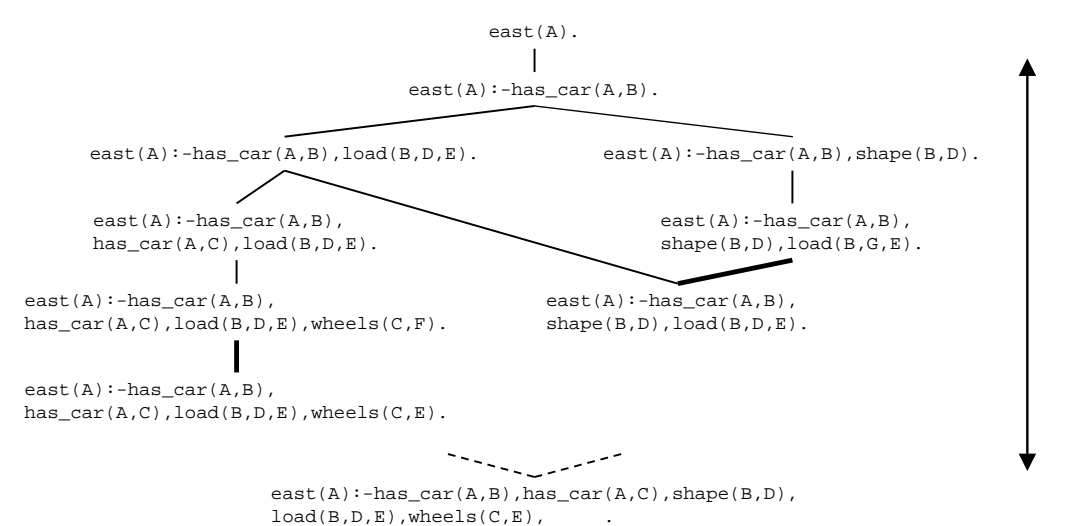

図 3 仮説空間の例 (一部)

ない範囲で与えられ，機能 2 で新たに追加されるリテラ ルは最弱仮説に含まれるリテラル，あるいは光れを一般 化したものに限られる，従って，生成される仮説は，最 弱仮説に含まれるリテラルのうちのいくつかを組み合わ せ，代入制約を緩和したものといえる .

Progol では Step 2 における探索を A*-like アルゴリ ズムに基づいて行ない，ILP/SE では共生進化に基づい て行なう．また，訓練事例におけるノイズに対処するた め, Progol カ深索中の仮説の被覆事例数における負事例 の割合を制限しているが，ILP/SE は被覆負事例数が上 限値 $T_{n e g}$ を超える仮説 $h_{i}$ を $H$ に加えないようにして いる . 後者の場合 $H$ が空になる可能性があるが , 後述の ように評価関数で被覆負事例数を考慮しているため, 弚 の可能性は非常に低いと考えられる .

\section{3. 共生進化に基づく未知事例分類}

\section{$3 \cdot 1$ 最適仮説探索への共生進化の適用}

Moriarty らの提案した共生進化では, 部分解を個体と する集団と，部分解の組み合わせで表現される全体解の 集団を並行して進化させ，最適解を導出する.最弱仮説 に含まれるリテラルを適度に一般化し, 必要なリテラル のみを組み合わせた節が最適仮説になることから，部分 と全体をバランスよく最適化する共生進化は，最適仮説 探索に適用できると考えられる．乥こでILP/SEでは， 仮説を全体解，リテラルを部分解として，図 1 のStep 2 を共生進化により行なう. 部分解と全体解の集団の進化 が, 弚れぞれ精密化演算子の機能 1 と機能 2 による特殊 化の度合の学習に相当する。

\section{$3 \cdot 2$ 最弱仮説配列}

ILP/SE の最適仮説探索では, 逆伴意法により生成さ れた最弱仮説と，モード宣言およびタイプ情報を利用す る.モード宣言にはモード ID と呼ばれる通し番号が振 られており，最弱仮説のリテラルはモード宣言のいずれ か 1 つと対応付けられている.リテラルとモード宣言の 対応はリテラルの述語名や項の属性等から決定されるが，

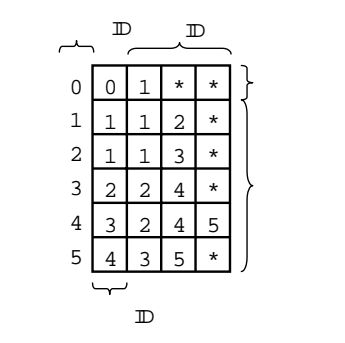

図 4 最弱仮説配列（一部）

一意に定まらない場合は, リテラルをより一般化できる ように, 対応可能なモード宣言のうち出力引数の個数が 最も多いものと対応付けられる.

最弱仮説中のリテラルにはリテラル ID が付与される . ボディのリテラル数を $N_{l i t}$ 個とすると, リテラル ID は ヘッドが 0 ，ボディが $1 〜 N_{l i t}$ となる.最弱仮説に含まれ る変数が $N_{v}$ 種類, 定数が $N_{c}$ 種類であるとき, 各変数を 正の整数 $1 \sim N_{v}$, 各定数を負の整数 $-1 \sim-N_{c}$ で表し， これを項 ID と呼ぶ. 同じ変数, 同じ定数では, 等しい 項 ID で表現される .

最弱仮説は, $\left(N_{l i t}+1\right) \times\left(N_{\text {term }}+1\right)$ の整数配列と して保持される.$N_{\text {term }}$ は各リテラルの項数の最大值で ある.該当するリテラル ID の行にモード ID と項 ID を 入れて最弱仮説配列を生成する . 図 2 のモード宣言 (モ一 ドID は上から順に 0〜4) と図 3 の最弱仮説を受け取っ た場合の最弱仮説配列の一部を图 4 に示す. 項 ID の 1〜 5 は光れ光れ変数 A〜E を表す. 最弱仮説配列の值をも とに，共生進化で扱う 2 集団の個体 atom および clause が生成される。

\section{$3 \cdot 3$ atom と atom 集団}

最適仮説探索における部分解を atom とする . atom は最弱仮説に含まれるリテラル，あるいは弚れを一般化 したリテラルであり，個体の性質を表す遺伝子型は 1 個 の述語遺伝子と $N_{\text {term }}$ 個の項遺伝子からなる配列で表現 される . 各 atom の元となっている最弱仮説中のリテラ ルを最弱リテラルと呼ぶ . 述語遺伝子には最弱リテラル のリテラル ID が入り，項遺伝子には対応する項のモー 
表 1 項遺伝子

\begin{tabular}{|c|c|}
\hline モード & 項遺伝子の值 \\
\hline$\#$ & 最弱リテラルの項 ID \\
\hline+- & 最弱リテラルの項 ID または 0 をランダムに選択 \\
\hline
\end{tabular}

ドによって表 1 のような値が入る. 項遺伝子の 0 は, 最 弱リテラルの項を一般化することを表す . 項数が $N_{t e r m}$ 個に満たないリテラルでは, 残りの項遺伝子は不定值と なる．表 1 に従って遺伝子の值を設定することで, 最弱 リテラルより特殊なリテラルの生成が回避される .

atom 集団の個体数 $S_{\text {apop }}$ は $\left(N_{l i t}+1\right) の R_{\text {apop }}$ 倍 ( $R_{\text {apop }}$ は任意の自然数) とする . 述語遺伝子が $0 \sim N_{l i t}$

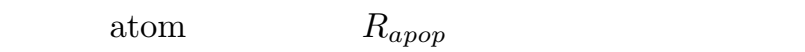
件を満たす範囲内でランダムに項遺伝子を決定して，初 期の atom 集団を形成する .

\section{$3 \cdot 4$ clause と clause 集団}

atom を組み合わせて構成される全体解を clause とす る . clause は仮説候補を表す節であり，長さ $\left(N_{l i t}+1\right)$ の atom へのポインタ配列で遺伝子型を表現する . $i$ 番 目の要素としては, リテラル ID が $i$ の atom へのポイ ンタ, あるいは空ポインタが入る. clause 集団の個体数 $S_{\text {cpop }}$ は最弱仮説のリテラル数 $\left(N_{l i t}+1\right)$ 以上とし， ラ ンダムに atom へのポインタを設定して , 初期の clause 集団の個体とする．ただし，すべての clause の任意の $i$ 番目の要素において, 少なくとも 1 つは空ポインタでな い要素が存在するようにする .

ランダムに clause を生成する際は, 次の手順に従う. Step 1 clause のすべての遺伝子を空ポインタとする . Step 2 atom 集団から atom を $1 つ$, ランダムに選択 する .

Step 3 選択した atom のリテラル ID が $i て ゙$, clause の $i$ 番目の遺伝子が空ポインタのとき, 選択した atom へのポインタを $i$ 番目の遺伝子とする .

Step 4 Step 2〜3を $N_{l i t}$ 回繰り返す.

繰り返しが終了した時点で, 0 番目の遺伝子，つまりへッ ドを表す遺伝子が空ポインタの場合は , 最弱仮説のヘッ ドと同じ atom へのポインタを入れ, ヘッドのない不正 な節の生成を避ける。

\section{$3 \cdot 5$ clause の表現型への変換}

clause の遺伝子が指している atom の遺伝子を参照し て，対応する節を表す表現型を生成する．このとき，次 の 2 つの制約条件を課し，条件を満たさない場合は光の リテラルを含まないものとする . 同時に clause の対応す る遺伝子は空ポインタに書き換えられる.

条件 1 ボディの+モードの項には既出していない変数 が出現しない.
表 2 項遺伝子が 0 のときの表現型における項

\begin{tabular}{|c|l|}
\hline モード & \multicolumn{1}{|c|}{ 項遺伝子の値 } \\
\hline+ & $\begin{array}{l}\text { 既出変数のうち, 最弱仮説で同変数だった項に現 } \\
\text { れる変数をランダムに選択 . 既出変数がなければ } \\
\text { 当該リテラルを削除 . }\end{array}$ \\
\hline- & $\begin{array}{l}\text { 最弱仮説で同変数だった項に現れている変数と新 } \\
\text { しい変数から , いずれか } 1 \text { つをランダムに選択 . }\end{array}$ \\
\hline
\end{tabular}

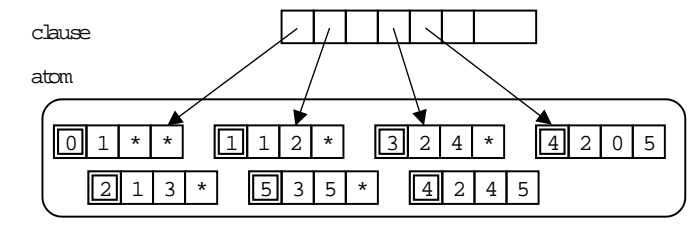

【 clauseの表現型】

east (A) : -has_car (A, B) , shape (B, D) , load (B, G, E) .

図 5 clause の遺伝子型と表現型

条件 2 ボディにのみ 2 回以上出現する変数の種類は $N_{\text {vmax }}$ 以下とする

条件 1 は, ボディの+モードの項に関して不正な節の生 成を回避するための必須条件である. 条件 2 は評価時間 の増大を防ぐために与えられた制約であり, 被覆事例数 を求める際のバックトラック発生を抑制する .

さらに, Progol 同樣, 生成される節のリテラル数に制 限を加える . clause の表現型への変換は, リテラル数が 上限值 $N_{\text {litmax }}$ に達したところで終了する . 参照されな かった遺伝子は空ポインタに書き換えられる．

atom の参照は, clause の各遺伝子に与えられた優先 度の高い順に行なう . 各遺伝子を下記のように 2 つのグ ループに分け, A グループには負の乱数を , B グループ には正の乱数を優先度として与える．

$\mathrm{A}$ グループ ヘッドの+モードの項ではない変数が , +

モードの項となっている atom を指す遺伝子

B グループ 上記以外のすべての遺伝子

atom の参照順序を設定することで，条件 1 による遺伝 子の空ポインタへの書き換えや，条件 2 によるリテラル ID の大きい atom の非参照を抑制する .

atom の項遺伝子の值が 0 以外のときは該当する変数 または定数を項の值とし，0のときは対応する項のモー ドによって表 2 のように值を決める . 最弱仮説配列が図 4 の場合の clause の遺伝子型と表現型の例を図 5 に示す. 5 番目の遺伝子か指す atom の遺伝子 0 は，表 2 に基づ き, 既出変数 D と最弱仮説に含まれていない新しい変数 Gからランダムに選ばれる .この例では G を選んで変換 している。

$3 \cdot 6$ 適応度関数と世代交代

atom と clause は適応度関数により評価され，集団内 での優劣が判定される . clause の評価は, 表現型の節が 被覆する事例数により決まる. clause $c$ が被覆する正事 例数と負事例数を兴れ光れ $p(c), n(c)$ と表すと, $c$ の適 
応度 $c f i t(c)$ は次式により求められる .

$$
\operatorname{cfit}(c)=p(c)-\alpha \cdot n(c)
$$

$\alpha$ は負事例の被覆をどの程度認めるかを表すパラメータ であり，1 以上の值を指定する．適応度の值が等しい場 合は表現型の節のリテラル数が少ない clause を優位と し, 適応度とリテラル数がともに等しい場合は前世代に おける優位度に従って, 各 clause 間の優位関係を一意に 決定する . atom の適応度は, 弚の atom を参照してい る clause のうち, 最も適応度の高い clause の適応度と する . atom $a$ を参照している clause の集合を $C_{a}$ とす ると, $a$ の適応度 $a f i t(a)$ は次式で定義される。

$$
\operatorname{afit}(a)=\max _{c_{i} \in C_{a}}\left(c f i t\left(c_{i}\right)\right)
$$

一世代での処理の流れは以下のようになる .

Step 1 各 clause の表現型を生成する .

Step 2 各 clause の適応度を算出する．

Step 3 各 atom の適応度を求める .

Step 4 atom を進化させる.

Step 5 clause を進化させる .

clause と atom の進化では, エリート保存率が $p_{k}$ であ るとき, 適応度が高い $S_{c p o p} \times p_{k}\left(\right.$ atom のときは $S_{a p o p}$ $\left.\times p_{k}\right)$ 個の個体は光のまま次世代に残す．残りの子孫は， 集団内での優位度に応じて選択した 2 つの個体を親とし て，1点交叉により生成する．リテラル ID が等しい atom 同士の交叉では, ランダムに交叉点を選択して 2 つの子 を生成し，いずれか 1 つを次世代に残す．リテラル ID が 異なる atom 同士を交叉させる場合には，モード宣言と タイプ情報による制約を満たさない項の発生を回避する ために，適応度の高い方の個体を谷のまま次世代に残す。 生成された子に対し，確率 $p_{m}$ でランダムに選択した 1 つの遺伝子に突然変異操作を施す．選択した遺伝子が述 語遺伝子の場合は, $0 \sim N_{l i t}$ の值をランダムに選んで置 き換え，述語遺伝子の值に応じて表 1 に矛盾しないよう に項遺伝子の值を変更する . 項遺伝子を選択した場合は 表 1 に従って遺伝子の値を変更する . clause の進化では， 参照している atom の述語遺伝子がStep 4 て変化してい る可能性があるため, 新しい atom に合わせて clause の 遺伝子を修正してから交叉と突然変異を行なう.

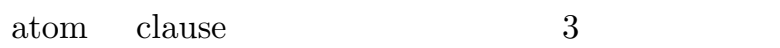
線によるアークをたどることに相当する .1 世代の進化 で複数のアークをたどり，空間内の仮説を評価する . 世 代を重ねるごとに探索領域は評価の高い節の周辺へと絞 られる. $N_{g}$ 世代 ( $N_{g}$ は任意の自然数) にわたって clause 集団の最良個体が変化しない場合, 弚の最良個体の表現 型を最適仮説とする .

\section{$3 \cdot 7$ クラス判 定}

GA では, 目標を反映した適応度関数に従って個体を 進化させることで最適解への収束を目指す．しかし, 初
期集団の生成や進化過程においてランダムな選択を行な うため, 弚の動作は再現不可能で, 実行ごとに多樣な解 か真出される.本来ならば，局所解への収束を回避し，実 行ごとに同一解が得られることか望ましいが，未知事例 分類では最適解の基準があいまいであるため, 目標を一 点に定めることができない，乥こで，GA の解の多樣性 を末知事例への適合可能性と捉え，複数の異なる解を利 用して未知事例のクラスを判定する.

前節までに記した共生進化に基づく最適仮説探索の手 法を用いて，同一の訓練事例による仮説生成を $R$ 回繰り 返す . 得られた $R$ 個の仮説 (節集合) $H_{1} \sim H_{R}$ により，未 知事例のクラス判定を行なう. 未知事例 $e$ を被覆する仮 説が $p(e)$ 個であるとき, $e$ のクラス $\operatorname{class}(e)$ は次式に 従って決定される。

$$
\text { class }(e)= \begin{cases}\text { positive } & \text { if } R / 2 \leq p(e) \\ \text { negative } & \text { otherwise }\end{cases}
$$

\section{$3 \cdot 8$ システム構成}

ILP/SE は，最適仮説探索を行なう探索モジュールと， 最弱仮説を生成し，最適仮説探索を制御する制御モジュー ル，未知事例を positive と negativeに分類するクラス判 定モジュールから構成される．ILP/SE のシステム構成 を図 6 に示す. 探索モジュールは C 言語, 制御モジュー ルは Sicstus Prologにより実装され，C インタフェース 部を介して動作する、制御モジュールで生成された最弱仮 説か探索モジュールに渡され，弚れに基づいて clause 集 団と atom 集団が形成されて，進化が進んでいく . clause を評価するときには，各 clauseの表現型が被覆する事例 数を制御モジュールに問い合わせる . clause 集団が収束 したときの最良個体の表現型を，最適仮説 $h_{i}$ として制 御モジュールに返す．すべての訓練事例が最適仮説 $h_{1} \sim$ $h_{n}$ により被覆されるまで最弱仮説生成と最適仮説探索を 行ない，節集合 $H_{j}=\left\{h_{1}, h_{2}, \cdots, h_{n}\right\}$ を仮説として出力 する. 以上の動作を $R$ 回繰り返して得られた仮説 $H_{1} \sim$ $H_{R}$ により, クラス判定モジュールが末知事例のクラス を決定する .

\section{4. 評 価 実 験}

提案手法の有効性を確かめるため，ILP/SE による評 価実験を行なった . 対象はILP システムのベンチマーク である Mutagenesis[Debnath 91] を用いた .ニトロ芳香 族化合物の突然変異性に関する 230 個のデータのうち， 重回帰分析式で判別可能な 188 個を使用した . 125 個が 突然変異について高活性, 63 個が低活性の化合物であり， 高活性化合物の性質に関するルール導出か課題である．

Srinivasan らの実験 [Srinivasan 95] に従い, 表 3 に示 す B1〜B4 の 4 種類の背景知識について 10-fold クロス バリデーションでの検証を行なった . ILP/SE において 


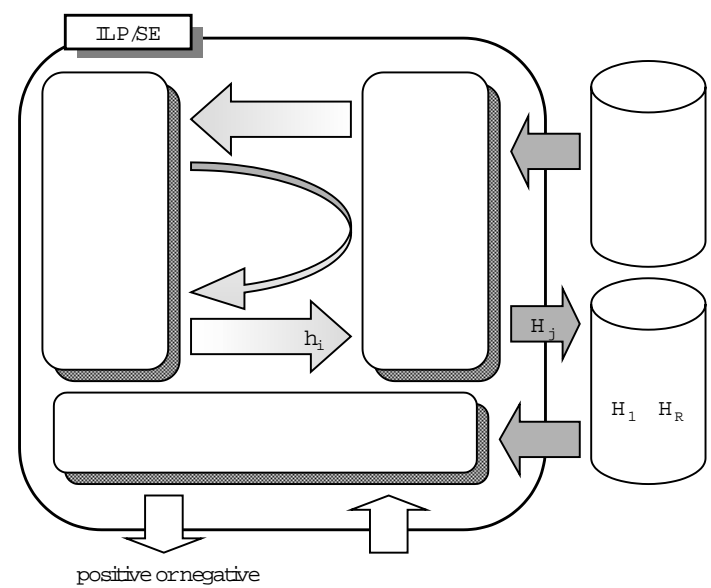

図 6 システム構成

表 3 背景知識

\begin{tabular}{|c|l|c|}
\hline 背景知識 & \multicolumn{1}{|c|}{ 内 容 } & 節の数 \\
\hline $\mathrm{B} 1$ & $\mathrm{~atm}, \mathrm{bond}$, 部分電荷の值 $(=)$ & 10137 \\
\hline $\mathrm{B} 2$ & $\mathrm{~B} 1+$ 部分電荷の值の範囲 $(\leq, \geq)$ & 10139 \\
\hline $\mathrm{B} 3$ & $\mathrm{~B} 2+\operatorname{lumo}, \log \mathrm{P}$ & 10512 \\
\hline $\mathrm{B} 4$ & $\mathrm{~B} 3+$ 構造に関する定義 & 11948 \\
\hline
\end{tabular}

表 4 パラメータ

\begin{tabular}{|l|r|}
\hline \multicolumn{1}{|c|}{ パラメータ } & \multicolumn{1}{|c|}{ 値 } \\
\hline エリート保存率 $p_{k}$ & 0.5 \\
突然変異確率 $p_{m}$ & 0.01 \\
適応度関数の $\alpha$ & 5 \\
収束条件 $N_{g}$ & 10 \\
リテラル数の上限值 $N_{l i t \max }$ & 4 \\
変数の種類数の上限値 $N_{v \max }$ & 2 \\
被覆負事例数の上限値 $T_{n e g}$ & 5 \\
atom 集団の個体数 $S_{\text {apop }}$ & $N_{l i t} \times 3$ \\
clause 集団の個体数 $S_{c p o p}$ & $\max \left(N_{l i t}, 30\right)$ \\
\hline
\end{tabular}

仮説生成を 20 回繰り返し，得られた複数個の仮説で多数 決を行なってテスト事例のクラスを判定した . 実験に用 いたパラメータを表 4 に示す.$p_{k}$ と $p_{m}$ は [Moriarty 96] に従って設定し， $N_{\text {litmax }}$ と $T_{\text {neg }}$ は [Srinivasan 95] と同 樣に設定した . $\alpha$ と $N_{g}$ は全データを訓練事例とテスト事 例の両方として用いる予備実験の結果から決定した．予 備実験で $\alpha$ を 2 8 で変化させたとき, $\alpha=5$ で平均正解 率が最大となった . また $N_{g}=100$ として同一の個体が 継続して最良個体となる世代数を調べた結果， $N_{g} \neq 100$ である世代数の平均は 2.28 世代で, $98 \%$ 以上が 10 世代 未満であった .

多数決によるクラス判定の効果を調べるために，20 回 の試行における平均正解率の推移を図 7 に示す . 各折れ 線は, $R$ 回目の試行で得られた仮説 $H_{R}$ を単独で用いて 分類を行なったときの訓練事例における平均正解率 (訓練 事例)，同じく単独仮説による分類のテスト事例における 平均正解率 (単独分類)， $R$ 回目の試行までに得られた $R$ 個の仮説 $H_{1} \sim H_{R}$ を用いて多数決で分類を行なったとき
表 5 平均正解率

\begin{tabular}{|c|c|c|}
\hline 背景知識 & Progol & ILP/SE \\
\hline B1 & $0.76(0.03)$ & $0.77(0.07)$ \\
B2 & $0.81(0.03)$ & $0.87(0.06)$ \\
B3 & $0.83(0.03)$ & $0.87(0.06)$ \\
B4 & $0.88(0.02)$ & $0.89(0.04)$ \\
\hline
\end{tabular}

の平均正解率 (多数決分類) の推移を表している. 訓練事 例における平均正解率は単独分類の場合よりも安定して おり，特に B2〜B4 の背景知識を用いた場合には $85 \%$ 以 上の高い正解率が得られていることから，共生進化によ る学習の収束性および訓練事例への適合性の高さが示さ れているといえる .

テスト事例における単独分類では, 訓練事例の場合と 比較して正解率が低いだけでなく, 試行ごとのばらつき も大きい . 訓練事例への適合を目標とした場合の未知事 例への適合性の低さが，低正解率とばらつきの主な原因 と考えられる. テスト事例において多数決分類を行なう と, 単独分類よりも高い正解率が得られ, 試行ごとの正 解率のばらつきも非常に小さい. 試行によって単独分類 の平均正解率が大きく変化しても，多数決を行なうこと で兴の変化による影響は抑えられ, 正解率の極端な低下 が回避されている．この実験結果は, 多数決によるクラス 判定に関して，ブースティングやバギングに代表される コミッティ学習と同樣の効果があることを示唆している． 各背景知識での正解率がほぼ安定している $R=14 \sim 20$ の平均正解率と Progol の平均正解率を表 5 に示す . 括 弧内の数字は標準偏差を表す．どの背景知識を用いた場 合にも，ILP/SE では Progol を越える正解率が得られて おり，特に B2，B3 における正解率は Progol を大きく 上回った .この結果，Mutagenesis における未知事例分 類の予測精度に関して, ILP/SE は Progol よりも優位で あることが示された .ただし, 本実験では変数の種類数 を 2 に制限しているため, 深い変数連鎖を必要とする問 題での性能については言及できない .

\section{5. 比較 研 究}

概念学習に GA を適用するいくつかの手法がこれまで に提案されてきた、概念記述が一階述語論理による場合 は, 学習すべきルールがどのようなリテラルを含み, ど の引数同士が等值関係にあるかなど , ルールの形式を既 定するパターンが末知であるため，個体の表現方法に工 夫を要する．REGAL[Giordana 96] では，ユーザがパ ターン (template と呼ゔ) を指定する . template はリテ ラルの連言であり，各リテラルには変数の取り得るすべ ての值を要素とする集合が引数に加えられている. 引数 間の等值関係は template により固定されており，各変 数が取るべき值のみを GA により学習する.

REGAL の後継である G-NET[Anglano 98] では， G- 


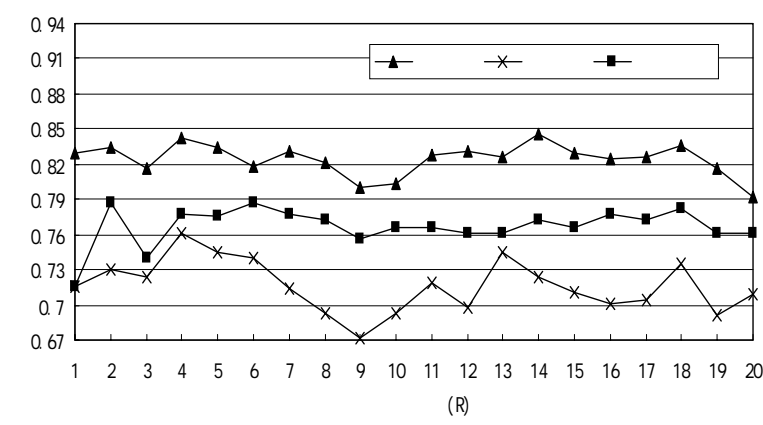

(i) B1

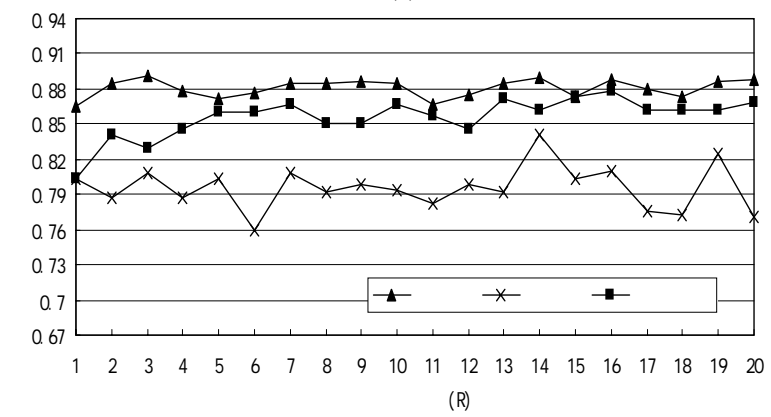

(iii) B3

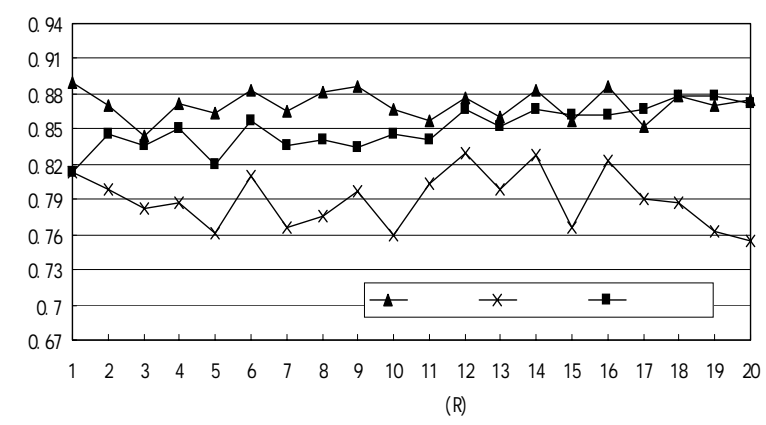

(ii) B2

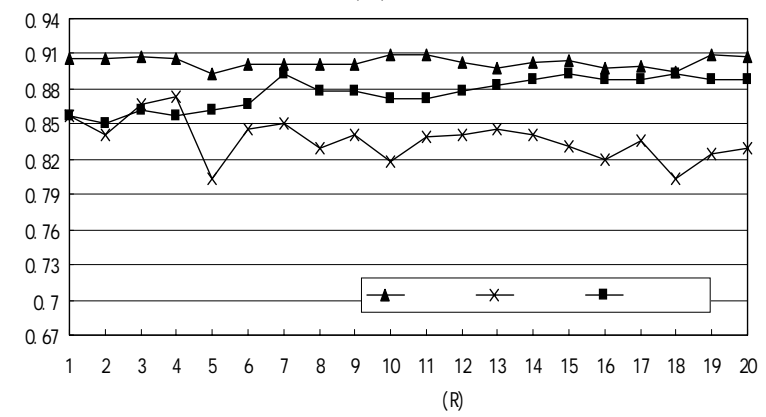

(iv) B4

図 7 正解率の推移

layer と Supervisor という 2 つのレベルで共進化を行 なう. G-layer では概念の部分定義 (1つの Horn 節) を GA により学習し, Supervisor では G-layer で生成され た Horn 節の選言である概念を評価して，弚の結果を Glayer の学習にフィードバックする . 樣々な問題において 高正解率が報告されているが, Mutagenesis では B3 の 背景知識で $91 \%$ の正解率が得られている.

G-NET と ILP/SE はともに共進化戦略 [Smith 93, Potter 95, Paredis 96] を採用しているが, 弚の個体の設 計方法や進化の流れは異なっている，G-NET では template をユーザか指定しなければならず, 引数の等值関係 は既定のものとされているのに対し，ILP/SEでは逆伴 意法により導出された最弱仮説をパターンとし，引数の 等値関係を含むルールを GA により学習できる点て優れ ているといえる .

REGAL と G-NET がユーザ指定のパターンに基づく のに対して , SIAO1[Augier 95] は seed として選んだ 1 つの正事例を満たすルールを一般化することで, 目標概念 を学習する.遺伝子操作オペレータの適用により, 述語の 一般化や変数間の等値関係をも学習できる. TamaddoniNezhad らは, Progol の逆伴意法と GA による最適仮説 探索とを統合するためのフレームワークを提案している [Tamaddoni-Nezhad 01] . 節をバイナリ行列で表現し， タスク依存の遺伝子操作オペレータを定義することで， 効率的な探索が可能となっている.ここで $\mathrm{N}$ 個の変数間 等值関係は $\mathrm{N} \times \mathrm{N}$ の対称行列の上三角部分で表現される． Braud らのシステムでは, 各変数の等値関係と数値制約 を等値クラスとしてコード化し, 集合操作に基づく遺伝
子操作オペレータで学習を行なう [Braud 01] . N 個の変 数間等値関係は長さ $\mathrm{N}$ の個体で表される.上記 3 つのシ ステムでは，簡易な問題による予備実験で良い結果が得 られているが, 実用データへの適用には至っていない．

複数仮説の多数決によるクラス判定法は, 反復学習に より得られた複数の分類器を用いて未知事例を分類する という点でコミッティ学習と類似している。一般に，信頼 度評価によるブースティング [Quinlan 96] では, 学習結 果が巨大なルール集合となり，理解が困難という欠点が ある・C $\mathrm{C}^{2} \mathrm{RIB}[$ Hoche 01] ではルール集合に制限を加え， 学習結果の理解性の増大と学習時間の短縮を実現してお り, Mutagenesis の B4 の背景知識で $88 \%$ の正解率が得

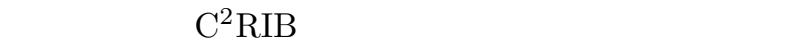
の節によって正しく分類されるように訓練事例の重みを 変化させながら節を 1 つずつ学習し, 得られた節の信頼 度による重みつき投票で未知事例を分類する .これに対 し ILP/SEでは, 学習時に訓練事例の設定や分類時の重 みが不要であり, 同一の訓練事例に関する学習を反復し， 単純な多数決を行なうだけで, $89 \%$ の正解率が得られて いる．また，確率的サンプリングの手法を用いたシステ ムSTILL[Sebag 00] も実現されており，Mutagenesisの B3 の背景知識で ILP $/ \mathrm{SE}$ と同じ $87 \%$ の正解率が得られ ている.

\section{6. おわりに}

本研究では, 未知事例における予測精度の向上を目的 として, 共生進化に基づく ILP の未知事例分類法を提案 
した . 精密化演算子の 2 つの機能を共生進化の 2 つの集 団の進化により実現し，最適仮説を探索した．また，従 来の探索では得られない解の多樣性を未知事例への適合 可能性と捉え, 複数回の仮説生成で得られた複数の仮説 により末知事例を識別することで, 予測精度の向上を目 指した . 提案手法を ILP システム ILP/SE として実現 し，Mutagenesis のデータを用いて実験を行なった結果， Progol を上回る正解率が得られた .この結果は, ILPの 学習方法として共生進化が有効であると同時に，多数決 によるクラス判定が未知事例の分類に有効であることを 示唆するものと考える

共生進化に基づく ILP の未知事例分類法は, $\mathrm{A}^{*}$-like ア ルゴリズム等の逐次探索を行なう場合と比較して , デー 夕量の増加に伴なう探索負荷の増加量が少ないため, 大 量データを対象とするデータマイニングへの効果が期待 される．今後は，生成される仮説の項でリスト等の構造 を扱うための拡張 , 多種の変数と深い変数連鎖を要する データでの評価を行なうとともに，大量データを対象と した場合の効率に焦点を当て , データマイニングの一手 法としての検討と改良を進めていく .

謝辞

本研究のシステムを構築するにあたり, 東京理科大学 大学院理工学研究科修士課程 1 年の伊藤政記君に多大な る協力を頂きました .ここに感謝の意を記します．

\section{$\diamond$ 参 考 文 献 $\diamond$}

[Anglano 98] Anglano, C., Giordana, A., Bello, G., and Saitta, L.: An Experimental Evaluation of Coevolutive Concept Learning, in Proc. of the 15th International Conference on Machine Learning, pp. 19-27 (1998).

[Augier 95] Augier, S., Venturini, G., and Kodratoff, Y.: Learning first order logic rules with a genetic algorithm, in Proc. of the 1st International Conference on Knowledge Discovery and Data Mining, pp. 21-26 (1995).

[Braud 01] Braud, A. and Vrain, C.: A Genetic Algorithm for Propositionalization, in Proc. of the 11th International Conference on Inductive Logic Programming, Lecture Notes in Artificial Intelligence, No.2157, pp. 27-40 (2001).

[Debnath 91] Debnath, A., Compadre, Lopez de R., Debnath, G., Schusterman, A., and Hansch, C.: StructureActivity Relationship of Mutagenic Aromatic and Heteroaromatic Nitro compounds. Correlation with molecular orbital energies and hydrophobicity, Journal of Medicinal Chemistry, Vol. 34, No. 2, pp. 786-797 (1991).

[古川 97] 古川康一:帰納論理プログラミングーチュートリアル 人工知能学会誌, Vol. 12, No. 5, pp. 655-664 (1997).

[Giordana 96] Giordana, A., Neri, F., and Saitta, L.: SearchIntensive Concept Induction, Evolutionary Computation, Vol. 3, No. 4, pp. 375-416 (1996).

[Hoche 01] Hoche, S. and Wrobel, S.: Relational Learning Using Constrained Confidence-Rated Boosting, in Proc. of the 11th International Conference on Inductive Logic Programming, Lecture Notes in Artificial Intelligence, No.2157, pp. 51-64 (2001)

[溝口 97] 溝口文雄 : 帰納論理プログラミングの適用方法につい て, 人工知能学会誌, Vol. 12, No. 5, pp. 675-682 (1997).

[Moriarty 96] Moriarty, D. and Miikkulainen, R.: Efficient
Reinforcement Learning through Symbiotic Evolution, $M a-$ chine Learning, Vol. 22, pp. 11-32 (1996).

[Moriarty 98] Moriarty, D. and Miikkulainen, R.: Hierarchical Evolution of Neural Networks, in Proc. of IEEE World Congress on Computational Intelligence, pp. 428433 (1998).

[Muggleton 95] Muggleton, S.: Inverse Entailment and Progol, New Generation Computing, Vol. 13, pp. 245-286 (1995).

[Paredis 96] Paredis, J.: Coevolutionary Computation, Artificial Life, Vol. 2, No. 4, pp. 355-375 (1996).

[Potter 95] Potter, M., De Jong, K., and Grefenstette, J.: A Coevolutionary Approach to Learning Sequential Decision Rules, in Proc. of the 6th International Conference on Genetic Algorithms, pp. 366-372 (1995).

[Quinlan 95] Quinlan, J. and Camereon-Jones, R.: Induction of Logic Programs: FOIL and Related Systems, New Generation Computing, Vol. 13, pp. 287-312 (1995).

[Quinlan 96] Quinlan, J.: Boosting first-order learning, in Proc. of the 7th International Workshop on Algorithmic Learning Theory, Lecture Notes in Artificial Intelligence, No.1160, pp. 143-155 (1996).

[Sebag 00] Sebag, M. and Rouveirol, C.: Resource-bounded Relational Reasoning: Induction and Deduction through Stochastic Matching, Machine Learning, Vol. 38, pp. 4162 (2000).

[Smith 93] Smith, R., Forrest, S., and Perelson, A.: Searching for Diverse, Cooperative Populations with Genetic Algorithms, Evolutionary Computation, Vol. 1, No. 2, pp. 127149 (1993).

[Srinivasan 95] Srinivasan, A., Muggleton, S., and King, R.: Comparing the use of background knowledge by two Inductive Logic Programming systems, in Proc. of the 5th International Workshop on Inductive Logic Programming, pp. 199-230 (1995).

[Tamaddoni-Nezhad 01] Tamaddoni-Nezhad, A. and Muggleton, S.: Using Genetic Algorithms for Learning Clauses in First-Order Logic, in Proc. of the Genetic and Evolutionary Computation Conference, pp. 639-646 (2001).

\section{〔担当委員 : 沼尾正行〕}

2001 年 10 月 12 日 受理

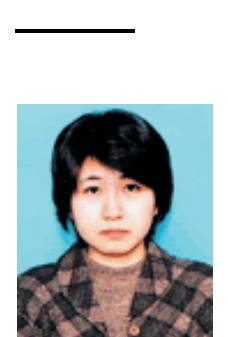

\section{紹 介}

\section{大谷 紀子(正会員)}

1993 年東京工業大学工学部情報工学科卒業. 1995 年同 大学院理工学研究科情報工学専攻修士課程修了. 同年キヤ ハン（株）入社．同社情報メディア研究所にて情報検索の 研究に従事. 2000 年東京理科大学理工学部経営工学科助 手. 2002 年武蔵工業大学環境情報学部情報メディア学科 講師. 情報処理学会, 電子情報通信学会各会員.

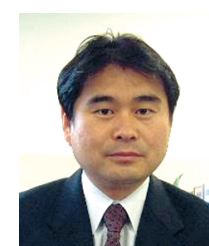

大和田 勇人 (正会員)

1983 年東京理科大学理工学部経営工学科卒業. 1988 年 同大学院理工学研究科経学工学専攻博士後期課程修了. 工 学博士. 同年同大学理工学部経営工学科助手. 現在は助教 授、データマイニング, 帰納論理プログラミングに興味を 持つ. 情報処理学会, 日本ソフトウェア科学会各会員 . 